\title{
Performance and serum cortisol concentration in Santa Inês lambs under different suckling schemes
}

\section{Ana Carolina Alves ${ }^{1}$, Nadja Gomes Alves ${ }^{1,2}$, Ivan Júnior Ascari ${ }^{3}$, Felipe Barbosa Junqueira ${ }^{3}$, Luciana França Smith Maciel ${ }^{4}$, Iraides Ferreira Furusho Garcia ${ }^{2}$, Renato Ribeiro Lima ${ }^{5}$}

\author{
${ }^{1}$ Universidade Federal de Lavras, Programa de Pós-graduação em Ciências Veterinárias, Lavras, MG, Brazil. \\ 2 Universidade Federal de Lavras, Departamento de Zootecnia, Lavras, MG, Brazil. \\ ${ }^{3}$ Universidade Federal de Lavras, Programa de Pós-graduação em Zootecnia, Lavras, MG, Brazil. \\ ${ }^{4}$ Universidade Federal de Lavras, Departamento de Medicina Veterinária, Lavras, MG, Brazil. \\ ${ }^{5}$ Universidade Federal de Lavras, Departamento de Ciências Exatas, Lavras, MG, Brazil.
}

\begin{abstract}
The objective of this study was to examine the effects of suckling schemes (continued, controlled, and total separation) and the type of pregnancy on performance and serum cortisol concentration in lambs. A total of 29 Santa Inês ewes and 40 lambs were used, and the randomized block design was applied in a split-plot scheme with a $3 \times 2$ factorial arrangement in the plot and time in the subplot. For controlled suckling, the diet was supplied twice daily during one hour, starting on their 10th day of life. Total and average daily intakes of concentrate dry matter of lambs that underwent total separation was higher than those of lambs under continued suckling. Lambs subjected to total separation demonstrated higher concentrate dry matter intake/weight gain ratio, lower total weight gain, lower average daily weight gain, and lower weaning weight than those subjected to continued and controlled suckling. Lambs from single pregnancy demonstrated higher weight gain and obtained higher weight at weaning. Lambs subjected to total separation have a developmental delay. However, the lower performance of lambs subject to total separation cannot be attributed to stress because there is a decrease in the serum cortisol concentration over time.
\end{abstract}

Key Words: artificial suckling, concentrate intake, controlled suckling, weight gain

\section{Introduction}

Controlled suckling or total separation of lambs after birth represent strategies with the potential to improve herd production rates because they allow the rapid postpartum return of ovarian cyclicity in ewes (Morales-Terán et al., 2004; Hernández et al., 2009; Assis et al., 2011). However, the lamb performance until weaning may be compromised by these management practices. Previous studies have assessed how the suckling scheme influences lamb performance until weaning (Morales-Terán et al., 2004; Costa et al., 2007; Leal et al., 2010), although none of these studies evaluated the effects of total separation between lambs and ewe. Therefore, it is possible that controlled or artificial suckling, combined with supplementary feeding of Santa Inês lambs, may influence lamb performance prior to weaning.

Received September 1, 2015 and accepted June 24, 2016

Corresponding author: nadja@dzo.ufla.br

http://dx.doi.org/10.1590/S1806-92902016000900007

Copyright (c) 2016 Sociedade Brasileira de Zootecnia. This is an Open Access article distributed under the terms of the Creative Commons Attribution License (http://creativecommons.org/licenses/by/4.0/), which permits unrestricted use, distribution, and reproduction in any medium, provided the original work is properly cited.
From a nutritional standpoint, energetic deficiency is considered a major cause for reduced weight development among lambs (Umberger, 2009). This problem is even more evident in lambs from twin pregnancy, as these animals are subject to "natural" suckling restrictions because the increase in milk production due to twin pregnancy does not achieve double the amount of milk produced by a sheep with a single lamb (Ramsey et al., 1994). Thus, creep feeding or private feeding during the suckling phase of lambs may be required to obtain satisfactory performance.

Stress levels can be assessed through quantification of the serum cortisol concentration, which typically increases when an animal is subjected to a stressful condition (Roussel, 2006). Sevi et al. (2003) reported that after the maternal bond is formed, behavioral, endocrine, and immunological changes can be observed in lambs as a result of the stress induced by maternal deprivation, which can compromise their performance. Thus, the effect of suckling schemes on serum cortisol concentration in lambs should be investigated further.

The objective of this study was to examine the effects of suckling schemes (continued, controlled, and total separation) and the type of pregnancy (single and twin) on the performance of Santa Inês lambs at weaning as well as the serum concentration of cortisol. 


\section{Material and Methods}

These experiments were conducted between March 2010 and January 2011 in Lavras, Minas Gerais, Brazil (21 ${ }^{\circ} 14^{\prime} 43^{\prime \prime} \mathrm{S}, 44^{\circ} 59^{\prime} 59^{\prime \prime} \mathrm{W}, 919 \mathrm{~m}$ altitude). This project was approved by the Ethics Committee for Animal Use of the University of Lavras and was registered under number CEUA/UFLA 042/10.

Twenty-nine Santa Inês pregnant ewes, at 1 to 3 years old, body weight (BW) of $52.60 \pm 1.76 \mathrm{~kg}$ (mean \pm standard error), body condition score (BCS) of 2.5 to 3.5 (0 to 5 scale, with $0=$ emaciated and $5=$ very fat; Gordon, 1997) and demonstrating good health and clinical conditions were used. During the first four months of pregnancy, the ewes were subjected to routine management of the sheep husbandry facilities. Briefly, the ewes were released in a Brachiaria decumbens pasture during the day $(7.00 \mathrm{~h}$ to $17.00 \mathrm{~h})$ and housed in collective pens containing supplements of corn silage and concentrate consisting of soybean meal, corn meal, minerals, and vitamins at night (between $17.00 \mathrm{~h}$ and $7.00 \mathrm{~h}$ ). Water and mineral salt were provided ad libitum.

During the last month of pregnancy, the ewes were confined in collective pens for feeding and received a complete diet twice daily in an amount sufficient to allow at least $10 \%$ leftovers. The diet was composed of corn silage $(73.5 \%)$, soybean meal $(7.0 \%)$, corn meal $(17.3 \%)$ and minerals (2.1\%), with $43.1 \%$ dry matter (DM), $12.4 \%$ crude protein (CP), 35.3\% neutral detergent fiber (NDF), $8.6 \%$ ash, $4.2 \%$ ether extract (EE), and $39.5 \%$ non-fibrous carbohydrate (NFC). The mineral salt used was composed of $155.0 \mathrm{~g} \mathrm{Ca}, 85.0 \mathrm{~g} \mathrm{P}, 5.0 \mathrm{~g} \mathrm{Mg}, 15.0 \mathrm{mg} \mathrm{S}, 140.0 \mathrm{~g} \mathrm{Na}$, $3500.0 \mathrm{mg} \mathrm{Zn}, 5000.0 \mathrm{mg} \mathrm{Mg}, 42.0 \mathrm{mg} \mathrm{I}, 15.0 \mathrm{mg} \mathrm{Se}$, $36.0 \mathrm{mg} \mathrm{Co}, 1000.0 \mathrm{mg} \mathrm{F}$, and $1000.0 \mathrm{mg} \mathrm{Mn}$. This diet was prepared according to the recommendations of the NRC (2007) to meet the nutritional requirements in late pregnancy. Water was provided ad libitum.

A randomized block design in a split-plot scheme, with a $3 \times 2$ factorial in the plot, was used. In total, three feeding schemes (continued, controlled, and total separation) and two types of pregnancy (single or twin) were evaluated. Six blocks were defined considering parity (primiparous and multiparous) and BW of the ewes at birth. The experiment was unbalanced, with three blocks containing the six treatments, one block containing five treatments, and two blocks containing only three treatments (for a total of 29 plots). Within each block, the ewes were randomly allocated to the treatments. The block with five plots did not contain the treatment related to continued suckling with twin pregnancy. The two blocks with three plots contained only the three suckling schemes for single-lamb pregnancies. The details of the three suckling schemes are listed as follows:

Continued suckling $(\mathrm{n}=9$ ewes and 12 lambs): The ewes remained in individual pens with their lambs, fulltime, until weaning at 60 days; Controlled suckling ( $\mathrm{n}=10$ ewes and 14 lambs): The lambs remained full-time with their mothers until the 9th day of life, but starting the afternoon on the 10th day of life they were separated and subjected to the controlled suckling scheme. The lambs were placed in the ewe pens twice a day at $7.00 \mathrm{~h}$ and $16.00 \mathrm{~h}$ for $1 \mathrm{~h}$ each session until weaning at 60 days. The ewes maintained auditory contact with the lambs, but without visual contact, at a distance of approximately $10 \mathrm{~m}$. The lambs were housed in individual pens $(1.0 \times 1.0 \mathrm{~m})$ and twin lambs were housed in the same pen. Total separation $(n=10$ ewes and 14 lambs): The lambs remained full-time with their mothers until the 9th day of life but were separated from their mothers beginning in the afternoon of the 10th day of life. The lambs received milk in a bottle twice daily, at $07.00 \mathrm{~h}$ and $16.00 \mathrm{~h}$. Sheep milk to cow milk transition was performed, to gradually replace the sheep milk for cow milk (Table 1). The ewes did not maintain visual or auditory contact with their lambs, which were placed at a distance of approximately 70 meters in individual pens $(1.0 \times 1.0 \mathrm{~m})$. Twin lambs were housed in the same pen.

The ewes were confined in individual pens $(2.7 \times 1.0 \mathrm{~m})$ after lambing and received a complete diet, calculated according to the NRC (2007) criteria to meet the nutritional requirements for early lactation. This diet was composed of corn silage (63.7\%), soybean meal $(22.2 \%)$, corn meal (12.1\%), minerals $(2.0 \%)$, and the chemical composition was DM (41.8\%), CP (19.1\%), NDF (29.4\%), ash (6.8\%), EE (5.1\%), and NFC (39.6\%). The mineral salt used was described previously. This diet was provided ad libitum twice a day $(7.00 \mathrm{~h}$ to $16.00 \mathrm{~h})$, with a sufficient amount to leave at least $10 \%$ as leftovers. The orts from each pen were removed and weighed daily before the feed supply, allowing an adjustment of the amount of feed. Water was provided ad libitum.

Table 1 - Sheep to cow milk transition and volume offered daily to lambs subjected to total separation

\begin{tabular}{lccccc}
\hline \multirow{2}{*}{ Age (days) } & \multicolumn{2}{c}{ Sheep milk } & & \multicolumn{2}{c}{ Cow milk } \\
\cline { 2 - 3 } \cline { 5 - 6 } \cline { 5 - 6 } \% Sheep milk & $\mathrm{kg} /$ day & & \% Cow milk & $\mathrm{kg} /$ day \\
\hline $1-9$ & 100 & - & & - & - \\
$10-16$ & 75 & 870 & & 25 & 288 \\
$17-23$ & 50 & 580 & & 50 & 577 \\
$24-30$ & 25 & 290 & & 75 & 866 \\
$31-37$ & 0 & 0 & & 100 & 1155 \\
$38-60$ & 0 & 0 & & 100 & 577 \\
\hline
\end{tabular}


Two daily milkings were performed in ewes that were totally separated from their lambs between 11 and 24 days postpartum. One daily milking was performed between days 25 and 31, and a single milking every other day was performed between days 32 and 36. Thus, the milking frequency decreased gradually, allowing the drying-off procedure of the ewes at day 36. Each ewe was milked again in cases of udder edema. Ewes were held in an appropriate trunk and received 5 IU of oxytocin (Oxytocin Forte UCB, Uzinas Chimicas Brasileiras, Jaboticabal, Brazil) via intramuscular injection to enable milking. The udder was disinfected with a pre-dipping solution at the concentration of $0.5 \%$ iodine and then dried with a paper towel.

The lambs in all treatment groups had access to starter concentrate pellets from the 7th day of life, provided in the proportion of $10 \%$ of their BW until weaning at 60 days. Tifton 85 hay with $6 \% \mathrm{CP}$ was provided ad libitum to lambs in all treatment groups from the 5th week of life. The starter concentrate was composed of corn meal (7.2\%), soybean meal $(21.3 \%)$, sodium monensin (Rumensin ${ }^{\circledR}$, Elanco, Itapira, Brazil) (0.035\%), sugar (2.3\%), minerals (4.0\%), and the chemical composition was DM (86.5\%), CP (18.5\%), NDF (13.3\%), ash (6.6\%), EE (3.9\%), NFC $(50.6 \%)$, and sodium monensin $(35.0 \mathrm{mg} / \mathrm{kg})$. The mineral salt used was described previously. Lambs subjected to continued suckling received the concentrate pellets in a private trough inside of the ewe pen. The concentrate leftover from each pen was removed and weighed prior to the daily supply of DM and nutrient intake determination. In case of twin lambs, which were confined to the same pen, the average and estimated $\mathrm{BW}$ and the individual average intake were also considered. The hay intake was not measured.

Concentrate ingredient samples were collected once weekly and stored at $-20{ }^{\circ} \mathrm{C}$ prior to the chemical analysis. The composite samples for each ingredient were predried in an air oven for $72 \mathrm{~h}$ at $55^{\circ} \mathrm{C}$ and ground through a 1 -mm sieve in a Thomas-Wiley grinder, and a subsample from each pre-dried sample was dried at $100{ }^{\circ} \mathrm{C}$ for $24 \mathrm{~h}$ to determine the DM content. The $\mathrm{CP}$ and $\mathrm{EE}$ analyses were performed according to the AOAC (2004). Ash was evaluated following sample incineration at $550{ }^{\circ} \mathrm{C}$ for $6 \mathrm{~h}$. The NDF content was determined with an Ankon ${ }^{\circledR}$ Fiber Analyser (Ankon Technology Corporation Fairport, NY) according to Van Soest et al. (1991), using heat-stable $\alpha$-amylase. Non-fibrous carbohydrates were calculated with the following equation: $\mathrm{NFC}=100-(\mathrm{CP}+\mathrm{EE}+\mathrm{NDF}+\mathrm{Ash})$.

All lambs were weighed at birth and thereafter every seven days until weaning at 60 days. The weight measurements were always performed at the same time for evaluation of the average daily weight gain. Weighing was performed before the morning suckling of lambs subjected to controlled suckling and before the artificial feeding of those subjected to total separation.

Blood samples of approximately $8 \mathrm{~mL}$ were collected on the 10th (first day of the treatments) and 20th days after birth (10 days after the beginning of the treatments) to assess the serum cortisol concentration of the lambs. These days were chosen to evaluate the cortisol concentration on the first day of physical separation of lambs and ewes and on the 10th day after separation, when the lambs should be adapted to treatments. Samples were collected through jugular vein puncture using $25 \times 7 \mathrm{~mm}$ needles and Vacutainer tubes without anticoagulant. Approximately 40 min after collection, the blood was centrifuged at $1.509 \times \mathrm{xg}$ for 10 min to obtain the serum, which was frozen at $-20^{\circ} \mathrm{C}$. The serum cortisol concentration was measured by solidphase radioimmunoassay using a commercial kit (Cortisol Coat-A-Count ${ }^{\mathbb{B}}$, Siemens Health Care Diagnostics, Los Angeles, USA). The intra- and inter-assay coefficients of variation were $0.04 \%$ and $1.08 \%$, respectively.

Sibling lambs from twin pregnancies were kept in a single pen, which was considered the experimental unit for all variables. The effects of feeding scheme and type of pregnancy on the total concentrate intake, average daily concentrate intake, total weight gain, average daily weight gain, and total concentrate intake/total weight gain rate were analyzed using the SAS GLM procedure (Statistical Analysis System, version 9.1) with variance and $F$ test analysis. In this analysis, the time factor was not considered. The following statistical model was used:

$$
Y_{i j k}=\mu+\alpha_{i}+\beta_{j}+\alpha_{i} \beta_{j}+\omega_{k}+e_{i j k},
$$

in which $Y_{i j k}=$ observation in treatments $i$ and $j$ in blocks $k$; $\mu=$ constant inherent to the entire observation; $\alpha_{i}=$ effect of type of gestation $(i=1,2) ; \beta_{j}=$ feeding scheme effect $(j=1,2,3) ; \alpha \beta_{i j}=$ type of pregnancy vs. feeding scheme interaction effect $(i=1,2$, and $j=1,2,3) ; \omega_{k}=$ block effect $(k=1,2 . .6)$; and $e_{i j}=$ experimental error associated with observation $Y_{i j k}$, random with normal distribution, mean zero and variance $\sigma^{2}$.

Eight periods of seven days from the 7 th to the 55th day and a five-day period from the 56th to the 60th day were organized to analyze the concentrate DM intake. The weight from the 14th day was considered, and the birth weight was used as a covariate in the lamb BW analysis. Serum cortisol concentration was analyzed on the 10th day (start of feeding scheme) and on the 20th day of the experimental period. Concentrate DM intake and serum cortisol concentration were analyzed over time using the SAS MIXED procedure according to the statistical model 
defined below. For lamb BW analysis, the same model was used, but the term $b\left(X_{i j l}-\bar{X}\right)$ referring to covariate birth weight was included.

$Y_{i j k, l}=\mu+\alpha_{i}+\beta_{j}+\alpha_{i} \beta_{j}+\omega_{l}+\varepsilon_{i j k}+\tau_{k}+\alpha_{i} \tau_{k}+\beta_{j} \tau_{k}+\alpha_{i} \beta_{j} \tau_{k}+e_{i j k l l}$, in which $Y_{i j k, l}=$ subplots $i, j, k, l$ observed value $(i=1,2 ; j=$ $1,2,3 ; k=1, \ldots 6$; and $l=1, \ldots 8) ; \mu=$ constant inherent to every observation; $\alpha_{i}=$ type of gestation effect $(i=1,2) ; \beta_{j}=$ feeding scheme effect $(j=1,2,3) ; \alpha_{i} \beta_{j}=$ type of pregnancy vs. feeding scheme interaction effect; $\omega_{l}=$ block effect; $l=$ $1, \ldots 6) ; \varepsilon_{i j k}=$ random error associated with observation $Y_{i j k, l}$, in plot level; $\tau_{k}=$ time effect $(k=1,2 \ldots 8$ (concentrate intake and lambs weight), or $k=1,2$ (cortisol)); $\alpha_{i} \tau_{k}=$ type of pregnancy vs. time interaction effect; $\beta_{j} \tau_{k}=$ feeding scheme vs. time interaction effect; $\alpha_{i} \beta_{j} \tau_{k}=$ type of pregnancy vs. feeding scheme vs. time interaction effect; and $e_{i j k l}=$ experimental error associated with the observation $Y_{i j k, l}$, subplot level.

\section{Results}

The daily milk production of ewes subjected to total separation from the 10th to the 24th day postpartum was $651.2 \pm 30.6 \mathrm{~kg}$. Between days 25 and 31, the ewes produced $436.6 \pm 13.5 \mathrm{~kg} /$ day of milk, and this production was $411.0 \pm 16.4 \mathrm{~kg}$ between days 32 and 36 .

The average daily concentrate intake of lambs in each of the three feeding schemes (Figure 1) and lambs from single- and twin-pregnancies (Figure 2) increased linearly $(\mathrm{P}<0.05)$ until weaning.

The total and average daily concentrate DM intake by lambs subjected to total separation were higher $(\mathrm{P}<0.05)$ than those of lambs under continued suckling, but did not differ $(\mathrm{P}>0.05)$ between lambs subjected to continued and controlled suckling or between lambs subjected to controlled suckling and total separation (Table 2). Lambs subjected to total separation demonstrated lower $(\mathrm{P}<0.05)$ total weight gain and average daily weight gain but increased $(\mathrm{P}<0.05)$ concentrate DM intake/weight gain ratio compared with those from other management groups. The BW of lambs in each of the three suckling schemes increased linearly over the experimental period $(\mathrm{P}<0.05$; Figure 3$)$. The weaning weight of lambs subjected to continued suckling

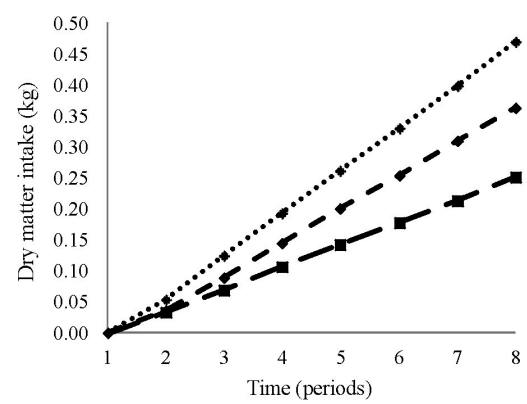

$\rightarrow \cdot$ Continued suckling $\mathrm{R}^{2}=0.98(\mathrm{P}<0.05)$

- Controlled suckling $\hat{y}=0.054 x-0.075$ $\mathrm{R}^{2}=0.97(\mathrm{P}<0.05)$

$\cdots \cdots$ Total separation $\hat{\mathrm{y}}=0.069 \mathrm{x}-0.084$ $\mathrm{R}^{2}=0.97(\mathrm{P}<0.05)$

Average daily intake differed over time $(\mathrm{P}<0.05)$.

Data represent periods of seven days from the 14th to 55 th day and five days from the 56th to 60th day of age.

Figure 1 - Average daily concentrate intake of Santa Inês lambs subjected to continued suckling, controlled suckling, and total separation.

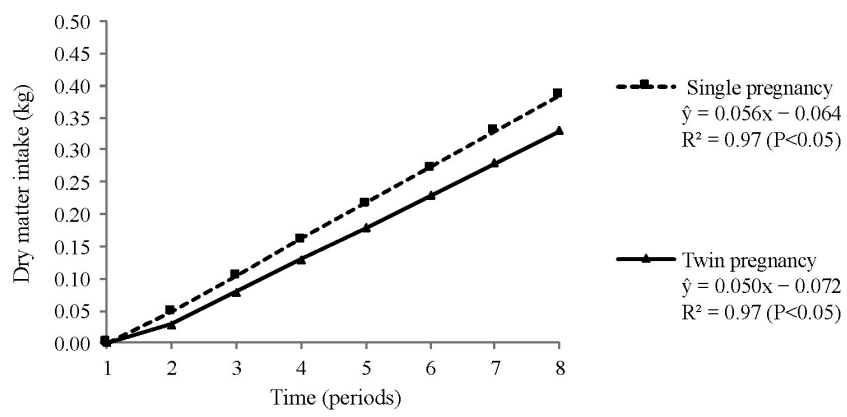

Average daily intake differed over time $(\mathrm{P}<0.05)$.

Data represent periods of seven days from the 14th to 55 th day and five days from the 56th to 60th day of age.

Figure 2 - Average daily concentrate intake of Santa Inês lambs from single and twin pregnancies.

Table 2 - Performance data from the 14th to 60th day after birth in lambs subjected to continued, controlled, or total separation feeding schemes and lambs from single and twin pregnancies (mean \pm standard error)

\begin{tabular}{|c|c|c|c|c|c|}
\hline & \multicolumn{5}{|c|}{ Performance measurement } \\
\hline & Intake $(\mathrm{kg} \mathrm{DM})^{1}$ & ADI (kg DM) & WG (kg) & ADWG (kg) & Intake/weight ${ }^{2}$ \\
\hline \multicolumn{6}{|l|}{ Suckling scheme } \\
\hline Continued & $6.58 \mathrm{a} \pm 1.12$ & $0.14 \mathrm{a} \pm 0.02$ & $12.00 \mathrm{a} \pm 0.67$ & $0.26 \mathrm{a} \pm 0.01$ & $0.55 \mathrm{a} \pm 0.10$ \\
\hline Controlled & $8.18 \mathrm{ab} \pm 1.46$ & $0.17 \mathrm{ab} \pm 0.03$ & $11.23 \mathrm{a} \pm 1.00$ & $0.24 \mathrm{a} \pm 0.02$ & $0.72 \mathrm{a} \pm 0.13$ \\
\hline Total separation & $11.26 b \pm 0.89$ & $0.24 b \pm 0.02$ & $8.31 \mathrm{~b} \pm 0.37$ & $0.18 \mathrm{~b} \pm 0.04$ & $1.33 \mathrm{~b} \pm 0.11$ \\
\hline \multicolumn{6}{|l|}{ Pregnancy } \\
\hline Single & $9.83 \pm 1.14$ & $0.21 \pm 0.02$ & $11.21 \mathrm{a} \pm 0.53$ & $0.24 \mathrm{a} \pm 0.01$ & $0.94 \pm 0.12$ \\
\hline Twin & $7.87 \pm 0.78$ & $0.17 \pm 0.01$ & $9.92 b \pm 0.73$ & $0.21 \mathrm{~b} \pm 0.01$ & $0.85 \pm 0.10$ \\
\hline
\end{tabular}

For comparisons between feeding schemes, means followed by different letters in the column differed according to Tukey-Kramer's test (P<0.05). For comparisons between types of pregnancy, means followed by different letters in the column differed according to the $\mathrm{F}$ test $(\mathrm{P}<0.05)$.

DM - dry matter; ADI - average daily intake of concentrate; WG - total weight gain; ADWG - average daily weight gain.

${ }^{1}$ Intake - total concentrate intake.

${ }^{2}$ Intake/weight - total concentrate intake $(\mathrm{kg} \mathrm{DM})$ and total weight gain ratio. 
was $19.07 \pm 1.04 \mathrm{~kg}$ (mean \pm standard error of the mean), and that of lambs subjected to controlled suckling was $18.59 \pm 1.09 \mathrm{~kg}$; there was no significant difference between these groups $(\mathrm{P}>0.05)$, but these results were higher $(\mathrm{P}<0.05)$ than that observed in lambs subjected to complete separation $(14.21 \pm 0.40 \mathrm{~kg})$.

The total and average daily concentrate DM intakes and the concentrate intake/weight gain ratio did not differ
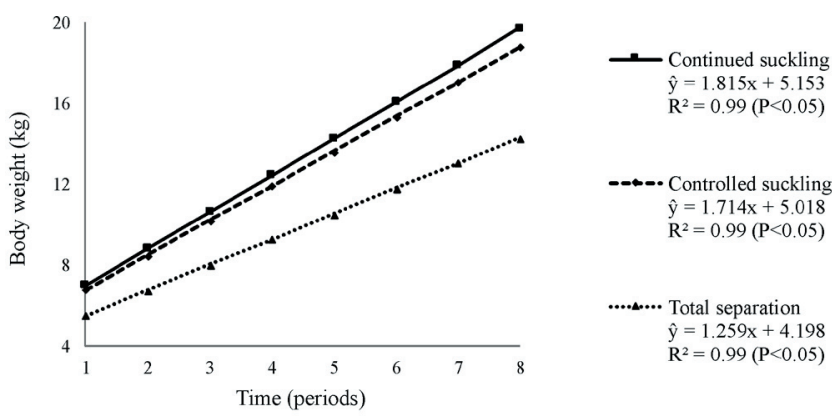

Body weights differed over time $(\mathrm{P}<0.05)$.

Data represent the weights at $14,21,28,35,42,49,56$, and 60 days.

Figure 3 - Body weight of Santa Inês lambs subjected to continued suckling, controlled suckling, and total separation from the 14 th day until the 60 th day of age.

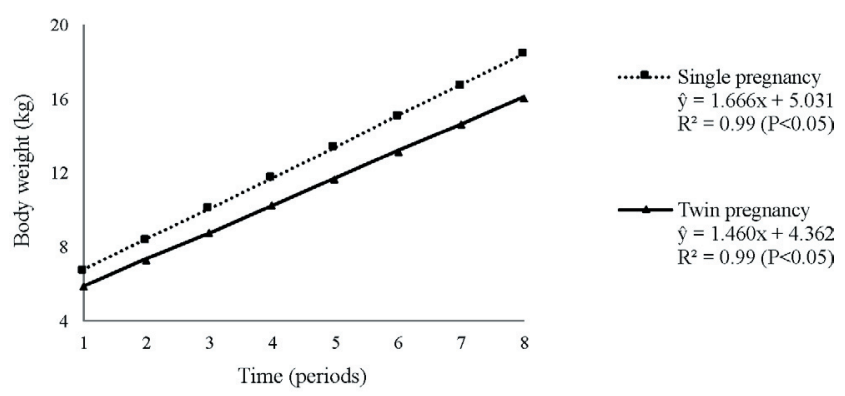

Body weights differed over time $(\mathrm{P}<0.05)$.

Data represent the weights at $14,21,28,35,42,49,56$, and 60 days.

Figure 4 - Body weights of Santa Inês lambs from single and twin pregnancies from the 14th day until the 60th day of age.

Table 3 - Serum cortisol concentration in lambs subjected to continued, controlled, or total separation feeding schemes and lambs from single and twin pregnancies (mean \pm standard error)

\begin{tabular}{lcc}
\hline & \multicolumn{2}{c}{ Serum cortisol concentration } \\
\cline { 2 - 3 } & 10th day $(\mathrm{ng} / \mathrm{mL})$ & 20th day $(\mathrm{ng} / \mathrm{mL})$ \\
\hline Suckling scheme & & \\
Continued & $21.32 \pm 3.66$ & $22.54 \pm 7.66$ \\
Controlled & $26.25 \pm 5.88$ & $6.84 \pm 2.40$ \\
Total separation & $32.31 \pm 5.00$ & $16.89 \pm 5.58$ \\
Pregnancy & & \\
Single & $26.45 \pm 3.55$ & $18.05 \pm 4.82$ \\
Twin & $27.39 \pm 5.27$ & $10.47 \pm 3.37$ \\
\hline
\end{tabular}

$(\mathrm{P}>0.05)$ between lambs from single and twin pregnancies (Table 2). The total weight gain and the average daily weight gain were higher $(\mathrm{P}=0.05)$ in lambs from single pregnancy (Table 2), and these animals also had higher $(\mathrm{P}<0.05)$ weaning weight in relation to animals from twin pregnancy (18.36 and $16.04 \mathrm{~kg}$, respectively, Figure 4).

The serum cortisol concentrations did not differ $(\mathrm{P}>0.05)$ between lambs subjected to continued, controlled, and total separation or between lambs from single or twin pregnancies (Table 3). There was no interaction between suckling scheme or type of pregnancy and time $(\mathrm{P}>0.05)$. However, there were differences between the two time periods studied $(\mathrm{P}<0.05)$, as the serum cortisol concentration in lambs on the 10th day of life was $26.81 \pm 2.91 \mathrm{ng} / \mathrm{mL}$, whereas that on the 20th day of life was $18.36 \pm 3.23 \mathrm{ng} / \mathrm{mL}$.

\section{Discussion}

The Santa Inês milk production reported by other authors (Susin et al., 2005; Ribeiro et al., 2007; Araújo et al., 2008; Ferreira et al., 2011) was generally less than 1.06 to $1.47 \mathrm{~kg} /$ day. However, the current experiment performed total lamb separation, whereas in other studies, the ewes and lambs were separated daily (Ribeiro et al., 2007) or once a week (Susin et al., 2005; Araújo et al., 2008; Ferreira et al., 2011), which may have stimulated greater milk production by ewes. The different doses of oxytocin used (Araújo et al., 2008) may have also contributed to the differences observed between studies. The decrease in production observed during lactation course was similar to that reported by Araújo et al. (2008).

The lower intake of concentrate DM by lambs subjected to continuous suckling compared with total separation was expected, since those lambs had continuous access to breast milk. Thus, most of the nutritional requirements of lambs subjected to continuous suckling were supplied by milk, which resulted in a lower intake of the starter concentrate. The average daily intake of concentrate by lambs subjected to total separation was similar to that reported by Silva et al. (2012) in Santa Inês $\times$ Dorper lambs that received creep-feeding with unpelleted feed from the 14th day of life $(250 \mathrm{~g})$.

Lambs subjected to continuous and controlled suckling had higher weight gain than those subjected to total separation; consequently, the concentrate intake/weight gain ratio of artificially fed lambs was higher. These results suggest that total separation on the 10th day of life compromised the performance of lambs. Morales-Terán et al. (2004) also reported no difference in average daily 
weight gain between Pelibuey lambs subjected to continued or controlled suckling schemes until weaning at 63 days (186 and 174 g, respectively). However, Assis et al. (2011) observed that Santa Inês and Bergamácia lambs, which remained full-time with parental sheep, demonstrated a reduced mean weight gain (160 g) compared with those subjected to controlled suckling (195 g). These authors also provided the starter concentrate ad libitum and in private troughs for lambs that remained full-time with parental sheep but used a concentrate with a higher CP content $(20 \%)$ than that used in the current study.

Regarding weaning weight, the results of the current study are similar to those reported by Sousa (2009), who observed an average weight at 60 days of 18.2 and $18.8 \mathrm{~kg}$ when comparing Santa Inês lambs under continued or controlled feeding schemes, respectively, with supplementation of $200 \mathrm{~g}$ of commercial diets containing $18 \% \mathrm{CP}$ in the dry season. However, the results of the current study differ from those reported by Leal et al. (2010), who observed weights at 56 days of $13.26 \mathrm{~kg}$ in Santa Inês lambs subjected to continued suckling and $14.42 \mathrm{~kg}$ in lambs under controlled suckling. Leal et al. (2010) evaluated lambs kept on native pastures with access to elephant grass and Leucaena supplementation and commercial feed containing a lower CP content $(15 \%)$ than that of the starter concentrate (18.5\%) offered in this study. Lower weaning weights compared with those observed in this study were also reported by Costa (2003) in Santa Inês lambs provided access to corn silage and concentrate creepfeeding containing $18 \% \mathrm{CP}$; these animals were subjected to continued $(15.58 \mathrm{~kg})$ or controlled suckling twice a day for $1 \mathrm{~h}$ each session $(14.3 \mathrm{~kg})$.

Lambs subjected to total separation did not demonstrate a weight gain proportional to their concentrate DM intake, possibly due to differences in the chemical composition of sheep and cow milk. Maestá et al. (2010) also observed that Bergamácia lambs subjected to artificial suckling with cow milk from $48 \mathrm{~h}$ of life had lower weaning weights at 60 days than those subjected to controlled suckling (16.55 and $18.98 \mathrm{~kg}$, respectively), and these authors attributed the lower weaning weights of lambs artificially breastfed to the use of cow milk as a substitute.

The sheep milk is richer in nutrients than cow milk. In Santa Inês ewes, Alves et al. (2015) reported 16.97\% total solids, $5.77 \%$ fat, and $5.39 \%$ protein at the 10th day postpartum. Moreover, in contrast to cow milk, sheep milk is composed of fat globules that have a higher surface to enzymatic activity due to the reduced size and higher triglyceride percentage, which allows easier digestion. Furthermore, the fat-to-protein ratio in sheep milk is greater than that in cow milk (Campos, 2012). Sevi et al. (1999) suggested that the gradual transition from sheep milk to a commercial substitute $(47.8 \mathrm{~g} / \mathrm{kg} \mathrm{CP}, 44.9 \mathrm{~g} / \mathrm{kg}$ fat $)$ is important to minimize stress in artificially suckled Comisana lambs. These authors observed similar intake and lamb weight gain increases, except in lambs gradually separated from ewes, which demonstrated a compromised weight gain.

The average daily weight gain of lambs from single $(240 \mathrm{~g})$ and twin $(220 \mathrm{~g})$ pregnancies in this study was higher than that observed by Assis et al. (2011) in Santa Inês lambs from birth to weaning at 60 days $(203 \mathrm{~g}$ and $144 \mathrm{~g}$ in single and twin pregnancies, respectively). The lower weight gain of lambs from twin pregnancies may be attributed to the probable shortage of mother milk, because although ewes can increase their milk production due to twin pregnancy, this production is not twice the quantity produced by a ewe with single pregnancy (Ramsey et al., 1994). Snowder and Glimp (1991) observed that ewe milk production and the BW of lambs from single pregnancies were higher during all lactation stages when correlating the BW of lambs of single and twin pregnancies to the milk production of Rambouillet, Columbia, Suffolk, and Polypay sheep. According to these authors, ewes with a twin pregnancy produced $40-64 \%$ more milk than those with single pregnancies. Susin et al. (2000) reported 28 and $33 \%$ higher productions in the second and third weeks of lactation, respectively, in twin pregnancies of Santa Inês sheep compared with animals with single pregnancies.

The increased serum cortisol concentration observed on the first day of the suckling schemes compared with day 20 may suggest that the lambs adapted over time to different management practices to which they were subjected. Therefore, the lower performance of lambs subjected to total separation cannot be attributed to stress caused by this form of management. The serum cortisol concentrations of lambs in this study on the 20th day were similar to those reported by Hargreaves and Hutson (1990) and Minton et al. (1995), who found that the plasma concentration of this hormone in Merino sheep, without imposing any kind of stress, was $20 \mathrm{ng} / \mathrm{mL}$. In lambs gradually separated from their dams from day 12 of age, Sevi et al. (2003) reported $45.3 \mathrm{ng} / \mathrm{mL}$, whereas in lambs that remained with their dams, the serum cortisol concentration was $18.2 \mathrm{ng} / \mathrm{mL}$. Similarly, the authors did not observe differences between groups at 32 days of age. It is important to note that cortisol is a glucocorticoid hormone, which normally rises when the animal is subjected to a stressful condition and takes a few days to return to normal, although the pattern of discharge may vary between individuals (Roussel, 2006). 


\section{Conclusions}

Lambs subjected to total separation show reduced performance compared with lambs subjected to continued and controlled suckling, which demonstrates that this management practice is not efficient for sheep reared in intensive systems. Additionally, lambs from single pregnancies display increased performance and are heavier at weaning than those from twin pregnancies. The serum cortisol concentration reduced on the 20th day compared with the 10th day of experiment, suggesting adaptation to management.

\section{Acknowledgments}

The present study was funded by the Minas Gerais Research Foundation (Fundação de Amparo à Pesquisa do Estado de Minas Gerais - FAPEMIG) and the National Council for Scientific and Technological Development (Conselho Nacional de Desenvolvimento Científico e Tecnológico - CNPq).

\section{References}

Alves, A. C.; Alves, N. G.; Ascari, I. J.; Junqueira, F. B.; Coutinho, A. S.; Lima, R. R.; Pérez, J. R. O.; De Paula, S. O.; Furusho-Garcia, I. F. and Abreu, L. R. 2015. Colostrum composition of Santa Inês sheep and passive transfer of immunity to lambs. Journal of Dairy Science 98:3706-3716.

Araújo, R. C.; Pires, A. V.; Susin, I., Mendes, C. Q.; Rodrigues, G. H.; Packer, I. U. and Eastridge, M. L. 2008. Milk yield, milk composition, eating behavior, and lamb performance of ewes fed diets containing soybean hulls replacing coast cross (Cynodon species) hay. Journal of Animal Science 86:3511-3521.

Assis, R. M.; Pérez, J. R. O.; Souza, J. C.; Leite, R. F. and Carvalho, J. R. R. 2011. Influência do manejo de mamada sobre o retorno ao em ovelhas pós-parto. Ciência e Agrotecnologia 35:1009-1016.

AOAC - Association of Official Analytical Chemistry. 2004. Official methods of analysis of AOAC International. 19th ed. Washington, D.C.

Campos, L. 2012. Aspectos benéficos do leite de ovelhas e seus derivados. Available at: <http://www.casadaovelha.com.br/>. Accessed on: Aug. 15, 2013.

Costa, R. L. D. 2003. Avaliação do peso e do retorno ao estro em ovelhas e do desempenho ponderal de cordeiros, em ovinos da raça Santa Inês, de acordo com o manejo de amamentação. Dissertação (M.Sc.). Universidade Estadual do Norte Fluminense, Campos dos Goytacazes.

Costa, R. L. D.; Cunha, E. A.; Fontes, R. S.; Quirino, C. R.; Santos, L. E.; Bueno, M. S.; Otero, W. G. and Veríssimo, C. J. 2007. Desempenho reprodutivo de ovelhas Santa Inês submetidas à amamentação contínua ou controlada. Boletim de Indústria Animal 64:51-59.

Ferreira, M. C. I.; Borges, I.; Macedo Junior, G. L.; Rodriguez, N. M.; Penna, C. F. A. M.; Souza, M. R.; Gomes, M. G. T.; Souza, F. A. and Cavalcanti, L. F. 2011. Produção e composição do leite de ovelhas
Santa Inês e mestiças Lacaune e Santa Inês e desenvolvimento de seus cordeiros. Arquivo Brasileiro de Medicina Veterinária e Zootecnia 63:530-533.

Gordon, I. R. 1997. Controlled reproduction in sheep and goats. CAB International, Oxford.

Hargreaves, A. L. and Hutson, G. D. 1990. The stress response in sheep during routine handling procedures. Applied Animal Behaviour Science 26:83-90.

Hernández, P. P.; Valdez, V. M. H.; Sandoval, B. F.; Hernández, G. T.; Rivera, P. D. and Sánchez, J. G. 2009. Efecto del tipo de amamantamiento em la actividad ovárica postparto de ovejas Pelibuey y tasas de crescimiento de corderos em los primeros 90 dias de edade. Revista Científica 19:343-349.

Leal, T. M.; Nunes, J. F.; Salqueiro, C. C. M.; Salmito-Vanderley, C. S. B.; Nascimento, H. T. S. and Moura, A. A. A. 2010. Retorno ao estro pós-parto em ovelhas da raça Santa Inês: influência do manejo alimentar e da alimentação. p.560-577. In: Ciência e Tecnologia na pecuária de caprinos e ovinos. 1st ed. Ximenes, L.; Martins, G. A.; Morais, O. R.; Costa, L. S. A; Nascimento, J. L. S., eds. $\mathrm{BNB}$, Fortaleza.

Maestá, S. A.; Siqueira, E. R.; Fernandes, S.; Emediato, R. M.; Oliveira, A. A. and Stradiotto, M. M. 2010. Desempenho de cordeiras Bergamácia submetidas a dois sistemas de desmama. Acta Scientiarum. Animal Science 32:317-321.

Minton, J. I.; Apple, J. K.; Parsons, K. M. and Blecha, F. 1995. Stressassociated concentrations of plasma cortisol cannot account for reduced lymphocyte function and changes in serum enzymes in lambs exposed to restraint and isolation stress. Journal of Animal Science 73:812-817.

Morales-Terán, G.; Sánchez, J. G.; Real, C. S.; Pro-Martínez, A. and Sandoval, B. F. 2004. Amamantamiento continuo o restringido y su relación com la duración del anestro postparto em ovejas Pelibuey. Agrociencia 38:165-171.

NRC - National Research Council. 2007. Nutrient requirements of small ruminant. 1st ed. National Academy Press, Washington, DC, USA.

Ramsey, W. S.; Hatfield, P. G. and Wallace, J. D. 1994. Relationships among ewe milk production and ewe and lamb forage intake in Targhee ewes nursing single or twin lambs. Journal of Animal Science 72:811-816.

Ribeiro, L. C.; Pérez, J. R. O.; Carvalho, P. H. A. C.; Silva, F. F.; Muniz, J. A.; Oliveira-Júnior, G. M. and Souza, N. V. 2007. Produção, composição e rendimento em queijo do leite de ovelhas Santa Inês tratadas com ocitocina. Journal of Animal Science 36:438-444.

Roussel, S. 2006. Repeated transport and isolation during pregnancy in ewes: Effects on the reactivity to humans and to the their offspring after lambing. Applied Animal Behaviour Science 97:172-189.

Sevi, A.; Massa, S.; Annicchiarico, G.; Dell'Aquila, S. and Muscio, A. 1999. Effect of stocking density on ewes milk yield, udder health and microenvironment. Journal of Dairy Research 66:489-499.

Sevi, A.; Caroprese, M.; Annicchiarico, G.; Albernzio, M.; Taibi, L. and Muscio, A. 2003. The effect of a gradual separation from the mother on later behavioral, immune and endocrine alterations in artificially reared lambs. Applied Animal Behaviour Science $83: 41-53$.

Silva, M. G. B.; Monteiro, A. L. G.; Fernandes, S. R.; Silva, C. J. A.; Cruz, T. A.; Salgado, J. A.; Kowalski, L. H. and Costa, C. 2012. Desmame precoce e a suplementação com alimentos concentrados de cordeiros e seu efeito sobre as características morfológicas da pastagem e o consumo de forragem. Revista Portuguesa de Ciências Veterinárias 111:57-62.

Snowder, G. D. and Glimp, H. A. 1991. Influence of breed, number of suckling lambs and stage of lactation on ewe milk production and 
lamb growth under range conditions. Journal of Animal Science 69:923-930.

Sousa, H. L. L. 2009. Comparação dos efeitos das estações do ano e sistema de amamentação sobre o período de puerpério de ovelhas Santa Inês no nordeste do Pará. Dissertação (M.Sc.). Universidade Federal do Ceará, Fortaleza.

Susin, I.; Rocha, M. H. M. and Pires, A. V. 2000. Efeito do uso de bagaço de cana-de-açúcar in natura ou hidrolizado sobre o desempenho de cordeiros confinados. In: Anais da $37^{\text {a }}$ Reunião Anual da Sociedade Brasileira de Zootecnia, Viçosa, MG.
Susin, I.; Pires, A. V.; Mendes, C. Q.; Packer, I. U. and Araujo, R. C. 2005. Milk yield and milk composition of Santa Inês ewes. Journal of Animal Science 83(Suppl. 1):66.

Umberger, S. H. 2009. Feeding sheep. College of Agriculture and Life Sciences, Virginia Polytechnic Institute and State University, Virginia. Available at: $<$ https://pubs.ext.vt.edu/410/410-853/410853_pdf.pdf $>$. Accessed on: Aug. 2, 2013.

Van Soest, P. J.; Robertson, J. B. and Lewis, B. A. 1991. Methods for dietary fiber, neutral detergent fiber, and nonstarch polysaccharides in relation to animal nutrition. Journal of Dairy Science 74:3583-3597. 